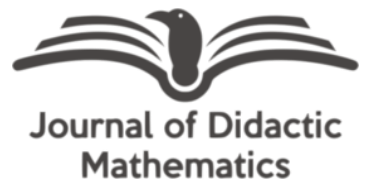

\title{
Analisis kesulitan kemampuan komunikasi matematika mahasiswa menggunakan aplikasi google classroom pada matakuliah aljabar
}

\section{Fitriani*}

Universitas Muhammadiyah Tapanuli Selatan, Padangsidimpuan, Sumatera Utara, Indonesia, 22716

\section{Yulia Anita Siregar}

Universitas Muhammadiyah Tapanuli Selatan, Padangsidimpuan, Sumatera Utara, Indonesia, 22716

\section{Wiwik Novitasari}

Universitas Muhammadiyah Tapanuli Selatan, Padangsidimpuan, Sumatera Utara, Indonesia, 22716

*Corresponding Author: fitriani@um-tapsel.ac.id

\begin{abstract}
Mathematical communication skills are one of the abilities that students must have to make it easier to solve problems contained in mathematics itself and in everyday life. Because if students have mastered mathematical communication skills, it will make it easier for students to take deeper learning. This study aims to analyze the difficulty of students' mathematical communication skills using the Google Classroom Application in the Algebra course. This type of research is descriptive qualitative. The subjects of this study were tree semester students who took Algebra courses in the Mathematics Education study program at Universitas Muhammadiyah Tapanuli Selatan, academic year $2020 / 2021$ as many as 15 people. The instrument used in this study was Test and interview. The results showed that based on the test results obtained: difficulties in the ability to interpret mathematical ideas rationally in writing, difficulties in mathematical problems into mathematical models and difficulties in the ability to express mathematical ideas in the form of descriptions. Meanwhile, based on the results of the interview, namely: (1) technical difficulties, and (2) student adaptation difficulties. To overcome these difficulties, it is necessary which is a combination of Online and Offline learning or also called blended learning.
\end{abstract}

Historis Artikel:

Diterima: 02 Maret 2021

Direvisi: 09 Maret 2021

Disetujui: 14 April 2021

Keywords:

Difficulty analysis;

mathematical

communication skills;

google classroom

Sitasi: Fitriani., Siregar, Y. A., \& Novitasari, W. (2021). Analisis kesulitan kemampuan komunikasi matematika mahasiswa menggunakan aplikasi google classroom pada matakuliah aljabar. Journal of Didactic Mathematics, 2(1), 1825. Doi: $10.34007 /$ jdm.v2i1.596

\section{PENDAHULUAN}

Menurut Majid (Rizqi, 2016) terdapat beberapa pengertian mengenai komunikasi. Pertama, pada dasarnya komunikasi merupakan suatu proses penyampaian informasi. Kedua, komunikasi adalah proses penyampaian gagasan dari seseorang kepada orang lain. Ketiga, komunikasi diartikan sebagai proses penciptaan arti terhadap gagasan atau ide yang disampaikan. Berdasarkan pengertian tersebut maka yang dimaksud dengan komunikasi ialaha merupakan cara seseorang dalam mengekspresikan ide yang ada di dalam pemikirannya baik secara lisan maupun tulisan. Komunikasi sangat dibutuhkan dalam dunia pendidikan terutama dalam dunia pendidikan matematika. Menurut NCTM (2000) bahwa kemampuan komunikasi matematika merupakan salah satu caranya berbagi ide dan memperjelas pemahaman. Simanjuntak \& Surya (2014) menyatakan bahwa kemampuan komunikasi matematika harus ditingkatkan, karena peningkatan komunikasi matematika siswa sangat berpengaruh dalam kemampuan siswa memahami matematika dan minat siswa dalam menguasai materi pelajaran matematika. Sehingga dapat 
Analisis kesulitan kemampuan komunikasi matematika mahasiswa...

dikatakan bahwa kemampuan komunikasi matematika sangatlah penting untuk dimiliki oleh siswa/mahasiswa guna untuk lebih memahami materi yang ada di dalam matematika itu sendiri.

Menurut NCTM (2000) bahwa kemampuan komunikasi sangat penting dari matematika dan pendidikan matematika. Surya \& Syahputra (2017); Paridjo \& Waluya (2017) menyebutkan bahwa keterampilan komunikasi matematika adalah kemampuan siswa untuk menggunakan matematika sebagai alat bantu komunikasi (bahasa matematika), dan kemampuan siswa untuk mengkomunikasikan matematika. Andriani (2020) menyatakan komunikasi matematika merupakan kemampuan seseorang dalam menyampaikan ide matematika baik itu berupa tulisan ataupun lisan. Menurut Haji (2014) Kemampuan komunikasi matematika adalah kemampuan dalam menyampaikan ide- ide matematika, baik secara lisan, tulisan maupun perbuatan. Menurut Mahmudi (Supandi, 2017) kemampuan komunikasi matematika adalah kemampuan untuk mengekspresikan ide-ide dan pemahaman matematika secara lisan dan tulisan menggunakan bilangan, simbol, gambar, grafik, diagram atau kata-kata. Sedangkan menurut Asikin (Wahyuningrum, 2013) komunikasi matematika dapat diartikan sebagai suatu dialog yang terjadi dalam suatu lingkungan kelas yang menghubungkan pemikiran siswa dengan guru atau siswa dengan siswa, sehingga transfer pesan tentang materi matematika yang dipelajari antara guru dan siswa atau antar siswa di kelas dapat terwujud. Berdasarkan beberapa defenisi terkait komunikasi matematika maka yang dimaksud dengan kemampuan komunikasi matematika ialah kemampuan dalam mengekspresikan ide-ide, simbol matematika dan pemahaman matematika ke dalam bentuk lisan maupun tulisan sehingga transpfer materi antara siswa dengan dosen dan dengan siswa lain dapat tercapai. Sutiawan (2020) mengemukakan ada 2 alasan penting yang menjadikan komunikasi perlu menjadi fokus perhatian dalam pembelajaran matematika menurut Baroody yaitu (1) mathematics as language; matematika tidak hanya sekedar alat bantu berpikir (a tool to aid thinking), alat untuk menemukan pola, atau menyelesaikan masalah namun matematika juga "an invaluable tool for communicating a variety of ideas clearly, precisely, and succintly," dan (2) mathematics learning as social activity; sebagai aktivitas sosial dalam pembelajaran matematika, seperti komunikasi antar siswa dan komunikasi antara guru dan siswa.

Adapun indikator kemampuan komunikasi matematika menurut Multazam (Sahrul, 2020) sebagai berikut: 1) Written Text, yaitu memberikan jawaban dengan menggunakan bahasa sendiri, membuat model situasi atau persoalan menggunakan model matematika dalam bentuk: lisan, tulisan, konkret, grafik dan aljabar, menjelaskan dan membuat pertanyaan tentang matematika yang telah dipelajari, mendengarkan, mendiskusikan dan menulis tentang matematika, membuat konjektur, menyusun argumen dan generalisasi. 2) Drawing, yaitu merefleksikan benda-benda nyata, gambar dan diagram dalam ide matematika, dan juga sebaliknya. 3) Mathematical Expression, yaitu mengekspresikan konsep matematika dengan menyatakan peristiwa sehari-hari dalam bahasa atau simbol matematika. Maka secara umum komunikasi matematik ada dua yaitu secara lisan dan tulisan. Namun komunikasi yang digunakan dalam penelitian ini ialah komunikasi matematika secara tulisan. Adapun indikator komunikasi matematis tertulis dalam penelitian ini yaitu: (1) kemampuan menginterpretasikan ide-ide matematika dengan rasional secara tertulis, (2) kemampuan mengubah permasalahan matematika kedalam model matematika, dan (3) Kemampuan mengekspresikan ide-ide matematika ke dalam bentuk uraian.

Permasalahan yang terjadi saat ini ialah tidak mungkinnya terjadi interaksi tatap muka di ruangan secara langsung karena melihat situasi yang sedang di hadapi oleh Indonesia bahkan Dunia yaitu masalah Wabah pandemi Covid-19. Untuk tetap terciptanya proses pembelajaran maka dilakukan proses pembelajaran jarak jauh dengan berbagai variasi model pembelajaran yang berbentuk Daring. Cukri dan Rahma (Nabila, 2020) menyebutkan bahwa pembelajaran daring juga disebutkan sebagai program penyelenggaraan kelas pembelajaran dalam jaringan. Model pembelajaran Daring yang digunakan dalam penelitian ini yaitu dengan menggunakan bantuan Aplikasi Google Classroom. Menurut Julia (Salamah, 2020), Google Classroom (atau dalam bahasa Indonesia yaitu Ruang Kelas Google) adalah suatu serambi pembelajaran campuran yang diperuntukkan terhadap setiap ruang lingkup pendidikan yang dimaksudkan untuk menemukan 
jalan keluar atas kesulitan dalam membuat, membagikan dan menggolong-golongkan setiap penugasan tanpa kertas. Menurut Nirfayanti \& Nurbaeti (2019), aplikasi google classroom dapat membantu Dosen dan Mahasiswa disebabkan karena baik Mahasiswa maupun Dosen dapat mengumpulkan tugas, mendistribusikan tugas, menilai tugas di rumah atau dimanapun tanpa terikat batas waktu atau jam pelajaran. Menurut Sabran (2019) google classroom adalah aplikasi yang dibuat oleh google yang bertujuan untuk membantu Dosen dan Mahasiswa apabila kedua hal tersebut berhalangan, mengorganisasi kelas serta berkomunikasi dengan para peserta didik tanpa harus terikat dengan jadwal kuliah di kelas. Sehingga dapat disimpilkan bahwa google classroom merupakan aplikasi yang memungkinkan terciptanya ruang kelas belajar di dunia maya tanpa bantuan kertas.

Aplikasi google classroom menurut Aris et al (2019) digunakan pada saat pembelajaran online, dimana aplikasi ini diharapkan dapat membantu proses pembelajaran jarak jauh yaitu dirancang dalam membuat dan membagikan materi pembelajaran, mengumpulkan tugas, dan memberikan nilai atau feedback dari tugas Mahasiswa. Penggunaan kelas online ini akan membuat pembelajaran menjadi lebih efektif bagi Dosen dan Mahasiswa karena pembelajaran tidak lagi dibatasi oleh ruang dan waktu. Disamping itu Mahasiswa nantinya dapat belajar, berdiskusi, mengerjakan tugas, dan ujian dari jarak jauh. Menurut Rahmanto (2020) pengoptimalan fitur google classroom memiliki dampak signifikan bagi pembelajaran di era digital, antara lain: (1) pembelajaran dengan memanfaatkan teknologi dilakukan secara daring, (2) fleksibel karena tidak terbatas oleh ruang dan waktu, (3) peserta didik secara mandiri terlibat langsung dalam proses pembelajaran yang memanfaatkan internet, (4) materi pembelajaran yang diberikan oleh pendidik mudah diakses oleh peserta didik, (5) meningkatkan keterampilan literasi data dan literasi teknologi .

Meskipun aplikasi google classroom sudah didesain dengan baik dan efektif namun masih ada kemungkinan kesulitan-kesuitan yang dihadapi oleh mahasiswa selama proses pembelajaran berlangsung, khususnya pada kesulitan kemampuan komunikasi matematika mahasiswa. Menurut Ismail (2016) kesulitan belajar adalah suatu kondisi di mana anak didik tidak dapat belajar secara maksimal disebabkan adanya hambatan, kendala atau gangguan dalam belajarnya. Adapun yang jenis kesulitan yang akan dipokuskan dalam penelitian ini yaitu kesulitan teknnis atau cara dan kesulitan adaptasi atau kebiasan-kebiasaan yang dihadapi mahasiswa selama pembelajaran daring dilaksanakan. Sehingga yang menjadi tujuan penelitian ini adalah untuk mendeskripsikan kesulitan-kesulitan kemampuan komunikasi matematika mahasiswa dalam menyelesaikan soal pada matakuliah Aljabar dengan menggunakan aplikasi google classroom.

\section{METODE}

Jenis Penelitian ini menggunakan pendekatan kualitatif deskriptif. Subyek penelitian ini adalah seluruh mahasiswa semester III yang mengambil matakuliah Aljabar pada program studi Pendidikan Matematika Universitas Muhammadiyah Tapanuli Selatan Tahun Ajaran 2020/2021 yaitu sebanyak 15 Orang. Tekhnik pengumpulan data yang digunakan dalam penelitian ini adalah tes dan wawancara bebas terpimpin secara langsung dengan bantuan aplikasi zoom meet dan google meet. Analisis data yang digunakan ialah deskriptif yang bertujuan mendesripsikan fenomena yang terjadi pada subjek terkait kesulitan-kesulitan yang dihadapi mahasiswa pada saat mengikuti pembelajaran google classroom. Kesulitan-kesulitan yang muncul dikelompokkan menjadi 2, yaitu kesulitan teknis dan kesulitan adaptasi mahasiswa.

\section{HASIL DAN PEMBAHASAN}

Berdasarkan hasil Tes tertulis terkiat kemampuan komunikasi matematika yang diberikan kepada seluruh mahasiswa yaitu sebanyak 15 orang, peneliti melakukan analisis terhadap hasil jawaban siswa pada soal Aljabar yang diberikan ditemukan kesulitan-kesuitan yang dialami mahasiswa. Berikut adalah salah satu hasil jawaban mahasiswa terhadap soal komunikasi matematika pada mata kuliah Aljabar yang sudah diberikan. 
Analisis kesulitan kemampuan komunikasi matematika mahasiswa...

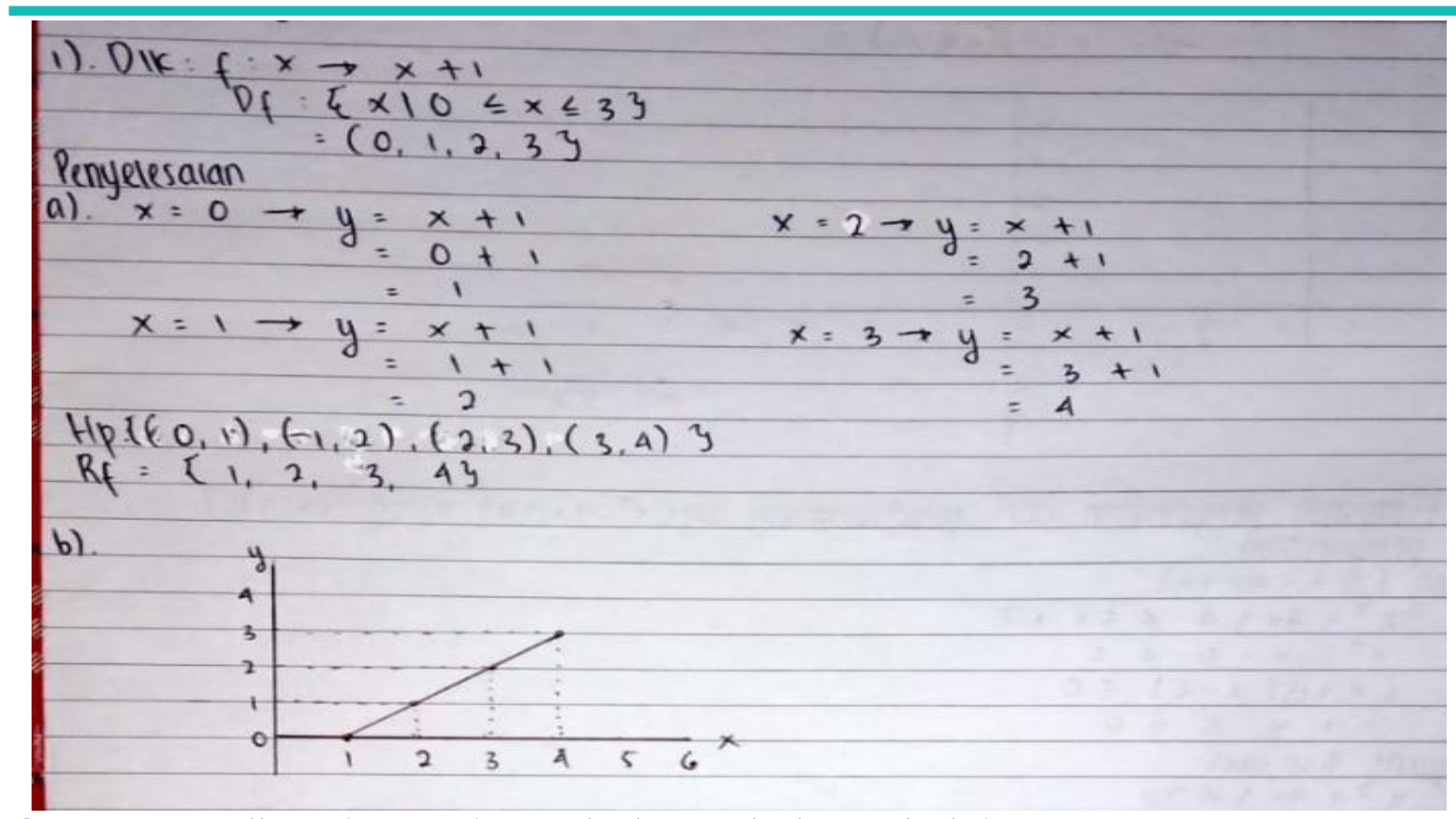

Gambar 1. Hasil Lembar Jawaban Mahasiswa terhadap Soal Aljabar

Berdasarkan salah satu hasil lembar jawaban mahasiswa terhadap soal aljabar yang diberikan, adapun kesulitan-kesuitan yang ditemukan ialah Mahasiswa : 1) Belum mampu menuliskan simbol matematika secara konsisten, 2) Belum mampu merumuskan ide matematika secara benar hal ini dapat dilihat pada penulisan himpunan Penyelesaian yang masih salah, 3) Pada jawaban point b dapat dilihat tidak sesuai gambar/grafik dengan Himpunan Penyelesaian, 4) Belum mampu mengekspresikan ide matematika kedalam bentuk gambar/grafik, 5) Berdasarkan digarma belum mampu membuat model matematika dengan benar, 6) Belum mampu membuat uraian dari hasil grafik. Sehingga dapat dinyatakan bahwa mahasiswa mengalami kesulitan terhadap kemampuan komunikasi matemataka pada indikator tertulis yaitu: Kemampuan menginterpretasikan ide-ide matematika dengan rasional secara tertulis, permasalahan matematika kedalam model matematika dan Kemampuan mengekspresikan ide-ide matematika ke dalam bentuk uraian.

Untuk memperkuat kesulitan yang terjadi maka peneliti melakukan wawancara bebas terpimpin guna mengetahui kesulitan-kesulitan yang dialami oleh mahasiswa terhadap kemampuan komunikasi matematika yaitu berupa kesulitan tekhnis dan kesulitan adaptasi mahasiswa terhadap penggunaan aplikasi google classroom selama proses pembelajaran berlangsung. Mahasiswa sebagai subjek penelitian diwawancarai satu per satu secara langsung dengan bantuan aplikasi room meet dan google meet. Hasil wawancara yang dilakukan terhadap 3 indikator kemampuaan komunikasi matematika yang sudah ditentukan sebelumnya akan dirangkum dari 15 Orang mahasiswa yang akan ditampilkan pada tabel berikut. Adapun hasil penelitian menunjukkan bahwa:

\section{Kesulitan Teknis}

Dapat diperhatikan pada hasil wawancara kesulitan teknis pada tabel 1 berikut, subjek mengungkapkan bahwa kesulitan yang dihadapi pada masing-masing indikator kemampuan komunikasi matematika yaitu: (1) Kemampuan menginterpretasikan ide-ide matematika dengan rasional secara tertulis: Sebagian Mahasiswa mengalami keterlambatan dalam menyampaikan ideide matematika secara tertulis di kolom jawaban apabila dalam penyelesaian soal diberikan batas waktu menjawab hal ini disebabkan susahnya jaringan internet di rumah/kampung dan juga paket internet yang digunakan sangat lambat; 
Tabel 1. Hasil Wawancara Tentang Kesulitan Teknis Mahasiswa

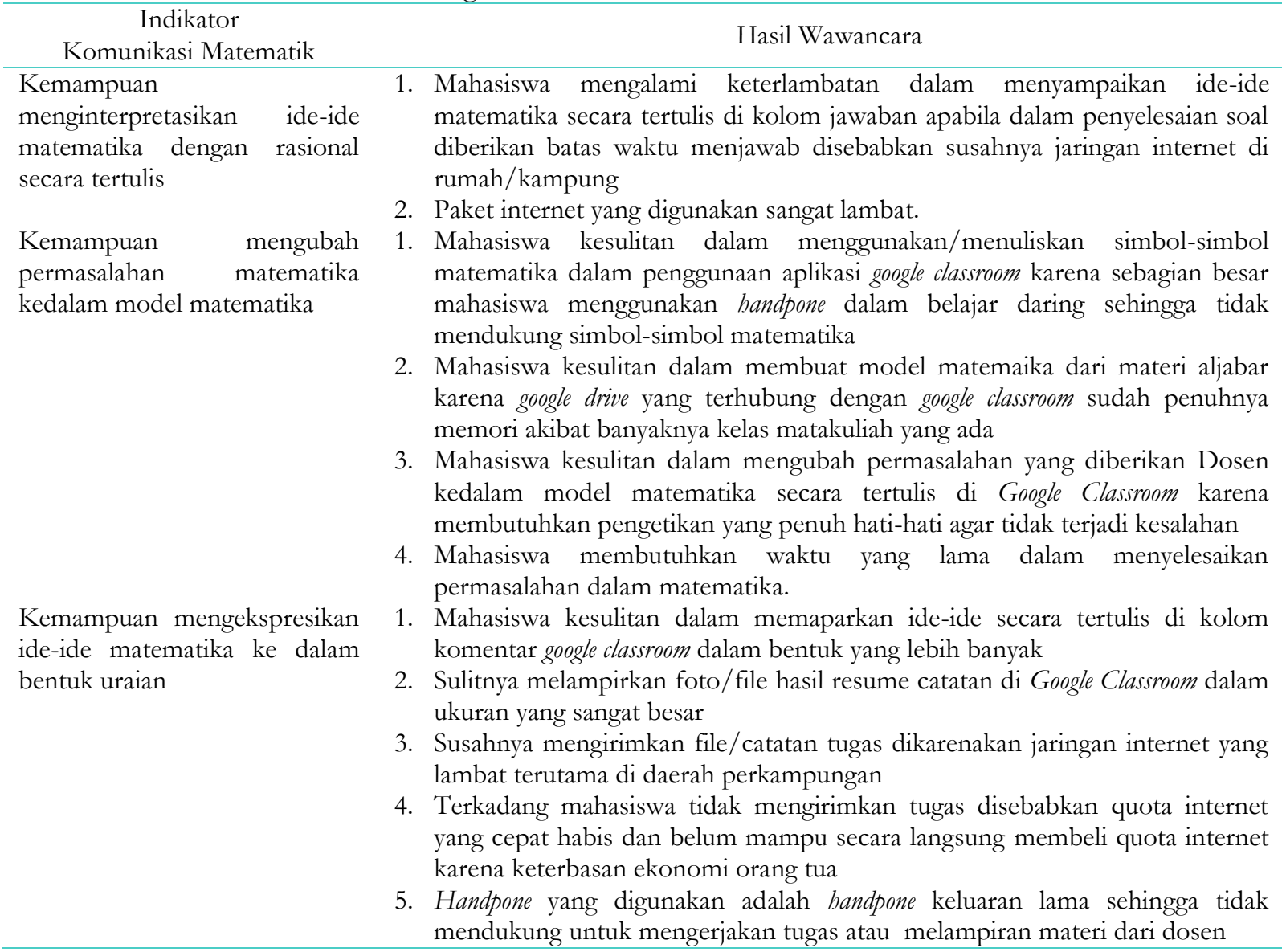

(2) Kemampuan mengubah permasalahan matematika kedalam model matematika: Mahasiswa kesulitan dalam menggunakan/menuliskan simbol-simbol matematika dalam penggunaan aplikasi google classroom karena sebagian besar mahasiswa menggunakan handpone dalam belajar daring sehingga tidak mendukung simbol-simbol matematika hal ini juga diperkirakan karena mahasiswa jarang mengetik simbol matematika, Mahasiswa kesulitan dalam membuat model matemaika dari materi aljabar karena google drive yang terhubung dengan google classroom sudah penuhnya memori hal ini disebabkan banyaknya kelas matakuliah yang ada, mahasiswa kesulitan dalam mengubah permasalahan yang diberikan Dosen kedalam model matematika secara tertulis di Google Classroom karena membutuhkan pengetikan yang penuh hati-hati agar tidak terjadi kesalahan, Mahasiswa membutuhkan waktu yang lama dalam menyelesaikan permasalahan dalam matematika; (3) Kemampuan mengekspresikan ide-ide matematika ke dalam bentuk uraian: Mahasiswa kesulitan dalam memaparkan ide-ide secara tertulis di kolom komentar google classroom dalam bentuk yang lebih banyak hal ini diperkirakan karena mahasiswa semuanya tidak memiliki laptop dalam menunjang belajarnya, sulitnya melampirkan foto/file hasil resume catatan di Google Classroom dalam ukuran yang sangat besar, susahnya mengirimkan file/catatan tugas dikarenakan jaringan internet yang lambat ini diperkirakan mahasiswa kebanyakan tinggal di daerah perkampungan, terkadang mahasiswa tidak mengirimkan tugas disebabkan quota internet yang cepat habis dan belum mampu secara langsung membeli quota internet ini disebabkan karena keterbatan ekonomi orang tua dan handpone yang digunakan adalah handpone keluaran lama sehingga tidak mendukung untuk mengerjakan tugas atau melampiran materi dari Dosen.

\section{Kesulitan Adaptasi Mabasiswa}

Dapat diperhatikan pada hasil wawancara kesulitan adaptasi Mahasiswa pada tabel 2 di atas, subjek mengungkapkan bahwa kesulitan yang dihadapi pada masing-masing indikator 
Analisis kesulitan kemampuan komunikasi matematika mahasiswa...

kemampuan komunikasi matematika yaitu: (1) Kemampuan menginterpretasikan ide-ide matematika dengan rasional secara tertulis: Mahasiswa sangat tidak terbiasa mengungkapkan ide matematika secara tertulis di aplikasi IT yang ada seperti Google Clasroom, mahasiswa merasa tidak percaya diri dalam menuliskan simbol-simbol matematika di kolom komentar yang tersedia, mahasiswa tidak terbiasa belajar sendiri, mahasiswa lebih suka belajar secara langsung/tatap muka dengan Dosen dan temannya hal ini semua diperkirakan karena selama ini mahasiswa sudah terbiasa belajarnya dibantu oleh Dosen dan teman;

Tabel 2. Hasil Wawancara Tentang Kesuliatan Adaptasi Mahasiswa

$\begin{array}{cc}\text { Indikator } & \text { Hasil Wawancara } \\ \text { Komunikasi Matematik } & \end{array}$

Kemampuan
menginterpretasikan
matematika dengan
secara tertulis

1. Mahasiswa tidak terbiasa mengungkapkan ide matematika secara tertulis di aplikasi IT yang ada seperti Google Clasroom

2. Mahasiswa merasa tidak percaya diri dalam menuliskan simbol-simbol matematika di kolom komentar yang tersedia

3. Mahasiswa tidak terbiasa belajar sendiri, mahasiswa lebih suka belajar secara langsung/tatap muka dengan Dosen dan temannya.

Kemampuan mengubah 1. Mahasiswa tidak mampu membuat model matematika dari permasalahan permasalahan matematika yang diberikan dosen

kedalam model matematika 2. Mahasiswa masih kurang memahami penggunaan simbil-simbol matematika yang ada pada materi sehingga tidak tau keguaannya

3. Mahasiswa tidak percaya diri menampilkan hasil jawabannya di tampilan google classroom karena akan dilihat oleh orang lain

4. Mahasiswa belum terbiasa merumuskan permasalahan matematika secara online

5. Mahasiswa terkendala dalam menuliskan model matematika karena handpone yang digunakan tidak mendukung simbol-simbol matematika

6. Mahasiswa lebih suka menulis di atas kertas secara langsung dibandingkan di atas layar.

Kemampuan mengekspresikan ide-ide matematika ke dalam bentuk uraian

1. Mahasiswa tidak terbiasa menampilkan ide-ide matematika dalam bentuk uraian

2. Mahasiswa kesulitan ketika menuliskan ide matematika dalam bentuk cerita

3. Mahasiswa tidak terbiasa menampilkan ide matematika dalam bentuk file

4. Mahasiswa tidak terbiasa mengetik simbol-simbol matematika dalam bentuk pesan

5. Mahasiswa tidak memiliki waktu yang banyak untuk menguraikan permasalahan matematika karena dirumah banyak pekerjaan rumah yang harus dikerjakan.

6. Mahasiswa merasa bosan ketika dihadapkan dengan belajar mandiri dalam waktu yang sangat lama

7. Mahasiswa tidak konsentrasi dalam menyelesaiakan permasalahan matematika karena suasana belajar di rumah sangat ribut.

(2) Kemampuan mengubah permasalahan matematika kedalam model matematika: Mahasiswa tidak mampu membuat model matematika dari permasalahan yang diberikan dosen, mahasiswa masih kurang memahami penggunaan simbil-simbol matematika yang ada pada materi sehingga tidak tau keguaannya, mahasiswa tidak percaya diri menampilkan hasil jawabannya di tampilan google classroom karena akan dilihat oleh orang lain, mahasiswa belum terbiasa merumuskan permasalahan matematika secara online, mahasiswa terkendala dalam menuliskan model matematika karena handpone yang digunakan tidak mendukung simbol-simbol matematika, mahasiswa lebih suka menulis di atas kertas secara langsung dibandingkan di atas layar; hal ini semua diperikrakan karena kurangnya kemampuan dasar matematika yang dimiliki oleh mahasiswa sehingga ketika dihadapkan dengan belajar mandiri terjadi kerisauan sendiri; (3) Kemampuan mengekspresikan ide-ide matematika ke dalam bentuk uraian: Mahasiswa tidak terbiasa menampilkan ide-ide matematika dalam bentuk uraian, mahasiswa kesulitan ketika menuliskan ide matematika dalam bentuk cerita, mahasiswa tidak terbiasa menampilkan ide matematika dalam bentuk file, mahasiswa tidak terbiasa mengetik simbol-simbol matematika 
dalam bentuk pesan, mahasiswa tidak memiliki waktu yang banyak untuk menguraikan permasalahan matematika karena dirumah banyak pekerjaan rumah yang harus dikerjakan. Mahasiswa merasa bosan ketika dihadapkan dengan belajar mandiri dalam waktu yang sangat lama, kesulitan ini semua diperkirakan karena kurangnya minat mahasiswa dalam mengembangkan potensi menulis dan mencoba yang ada pada diri mahasiswa, mahasiswa tidak konsentrasi dalam menyelesaiakan permasalahan matematika hal ini karena suasana belajar di rumah sangat ribut.

\section{KESIMPULAN}

Berdasarkan hasil pembahasan di atas dapat dijabarkan kesulitan-kesulitan kemampuan komunikasi matematika yang dihadapi mahasiswa semester III yang mengambil matakuliah Aljabar pada program studi Pendidikan Matematika Universitas Muhammadiyah Tapanuli Selatan Tahun Ajaran 2020/2021 sebanyak 15 Orang yaitu berdasarkan hasil tes diperoleh: kesulitan dalam kemampuan menginterpretasikan ide-ide matematika dengan rasional secara tertulis, kesulitan permasalahan matematika kedalam model matematika dan kesulitan kemampuan mengekspresikan ide-ide matematika ke dalam bentuk uraian. Sedangkan berdasarkan hasil wawancara yaitu: (1) Kesulitan teknis, meliputi sinyal internet, keterbatasan kuota internet, daerah tempat tinggal berada di kampung yang sulit terjangkau signal internet dan perangkat pendukung yang kurang memadai, serta penuhnya memori mahasiswa ketika akan mengirim jawaban (2) kesulitan adaptasi mahasiswa, tidak terbiasa mengetik/menulis, keadaaan rumah tidak kondusif, tidak terbiasa kuliah online, tuntutan pekerjaan dan kesulitan membagi waktu, serta kurangnya minat belajar mahasiswa. Adapun saran berdasarkan kesulitan yang ditemukan ialah (1) kesulitan teknis terkait kouta internet yaitu dengan mendaftarkan nomor handpone mahasiswa agar memperoleh bantuan kuota gratis dari kemendikbud, terkat signal internet yaitu mahasiswa jika hendak memasuki perkuliahan agar mencari jaringan yang lebih bagus (2) kesulitan adaptasi mahasiswa diselesaikan dengan pemberian motivasi dan apersepsi oleh dosen ketika pertama kali perkuliahan diberikan. Kemudian perlu dilaksanakan pembelajaran Merged yaitu perpaduan antara pembelajaran Daring dan Luring atau diebut juga dengan blended learning.

\section{DAFTAR PUSTAKA}

Andriani, S. (2020). Upaya Peningkatan Kemampuan Komunikasi Matematis Siswa. Journal on Teacher Education, 1(2), 33-38. https:// doi.org/10.31004/jote.v1i2.515

Aris, N., Erawaty, N., Massalesse, J., Sirajang, N., Wahda., Kasbawati., Thamrin, S. A., Sahriman, S., Ramadhan, M. N. B., \& Jaya, A. K. (2019). Peningkatan Kualitas Pembelajaran Matematika Bagi Guru SMA Melalui Media Google Classroom dan Geogebra (Bekerjasama dengan MGMP Matematika Kabupaten Bone). Jati Emas (Jumal Aplikasi Teknik dan Pengabdian Masyarakat), 3(2) 196-200.

Haji, S. (2014). Pengaruh Pembelajaran Kontekstual Terhadap Kemampuan Komunikasi Matematika Siswa SMP Kota Bengkulu. EXACTA, 10(2), 115-118.

Ismail, D. (2016). Diagnosis Kesulitan Belajar Siswa dalam Pembelajaran Aktif di Sekolah. Jurnal Edukasi: Jurnal Bimbingan Konseling, 2(1), 30-43. http://dx.doi.org/10.22373/je.v2i1.689

Nabila, H., \& Sulistiyaningsih. (2020). Analisis Kesulitan Belajar Matematika Dalam Pembelajaran Daring Berbantuan Microsoft Teams Kelas XI SMA Negeri 9 Semarang. Prosiding $1^{\text {st }}$ International Conference Education, Science, Technology "Science Education and Measurement Using Big Data for Society 5.0”Semarang, 1 Desember 2020.

NCTM. (2000). Principles and Standards for School Mathematics. United States of America: The National Council of Teachers of Mathematics, Inc.

Nirfayanti., \& Nurbaeti. (2019). Pengaruh Media Pembelajaran Google Classroom Dalam Pembelajaran Analisis Real Terhadap Motivasi Belajar Mahasiswa. Proximal: Jurnal Penelitian Matematika Dan Pendidikan Matematika, 2(1), 50-59.

Rahmanto, M. A., \& Bunyamin. (2020). Efektivitas Media Pembelajaran Daring Melalui Google 
Analisis kesulitan kemampuan komunikasi matematika mahasiswa...

Classroom. Jurnal Pendidikan Islam, 11(2), 119-135.
https://doi.org/10.22236/jpi.v11i2.5974

Rizqi, A. A. (2016). Kemampuan Komunikasi Matematis Siswa melalui Blended Learning Berbasis Pemecahan Masalah. PRISMA, Prosiding Seminar Nasional Matematika, 191-202. Retrieved from https://journal.unnes.ac.id/sju/index.php/prisma/article/view/21457

Sabran., \& Sabara, E. (2019). Keefektifan Google Classroom sebagai media pembelajaran. Prosiding Seminar Nasional Lembaga Penelitian Universitas Negeri Makassar "Diseminasi Hasil Penelitian melalui Optimalisasi Sinta dan Hak Kekayaan Intelektual", 122-125.

Sahrul, S., Yuanita, P., \& Maimunah, M. (2020). Pengembangan Perangkat Pembelajaran Matematika Berbasis Model Discovery Learning untuk Memfasilitasi Kemampuan Komunikasi Matematis Peserta Didik SMP Kelas VIII. Jurnal Cendekia: Jurnal Pendidikan Matematika, 4(2), 626-636. https://doi.org/10.31004/cendekia.v4i2.277

Salamah, W. (2020). Deskripsi Penggunaan Aplikasi Google Classroom Dalam Proses Pembelajaran. Jurnal Penelitian dan Pengembangan Pendidikan, 4(3), 533-538. http://dx.doi.org/10.23887/jppp.v4i3.29099

Simanjuntak, M., \& Surya, E. (2014). Peningkatan Kemampuan Representasi Dan Komunikasi Matematis Siswa Smp Pada Materi Transformasi Dengan Strategi Think-Talk-Write (TTW) Berbantuan Kartu Domino. Paradikma: Jurnal Pendidikan Matematika, 7(1). https://doi.org/10.24114/paradikma.v8i1.3355

Supandi., Rosvitasari, D. N., \& Kusumaningsih, W. (2017). Peningkatan Kemampuan Komunikasi Tertulis Matematis Melalui Strategi Think-Talk-Write. Jurnal Kependidikan, 1(2), 227-239.

Surya, E., \& Syahputra, E. (2017). Analysis Mathematical Communication Skills Student At The Grade Ix Junior High School. International Journal of Advance Research and Innovative Ideas in Education, 3(2), 2160-2164.

Sutiawan, H., Suyono., \& Wiraningsih, E. D. (2020). Pengaruh model pembelajaran kooperatif think talk write terhadap kemampuan komunikasi dan disposisi matematis ditinjau dari kemampuan awal matematika siswa. JPPM (Jurnal Penelitian dan Pembelajaran Matematika), 13(1), 33-46. http://dx.doi.org/10.30870/jppm.v13i1.2790

Wahyuningrum, E. (2013). Pengembangan Kemampuan Komunikasi Matematik Siswa SMP Pengembangan Kemampuan Komunikasi Matematik dengan MEAs (Developing Mathematical Communication Skills For Junior High School Students). Jurnal Pendidikan, 14(1), 1-10. https://doi.org/10.33830/jp.v14i1.346.2013

Paridjo., \& Waluya, S. B. (2017). Analysis Mathematical Communication Skills Students In The Matter Algebra Based NCTM. IOSR Journal of Mathematics (IOSR-JM), 13(1), 60-66. https://doi.org/10.9790/5728-1301056066 